\title{
Article \\ Multi-Attribute Rating Method for Selecting a Clean Coal Energy Generation Technology
}

\author{
Wioletta Lipka (1) and Cezary Szwed * \\ Faculty of Management, Warsaw University of Technology, 00-661 Warszawa, Poland; wioletta.lipka@pw.edu.pl \\ * Correspondence: cezary.szwed@pw.edu.pl; Tel.: +48-22-849-94-43
}

Citation: Lipka, W.; Szwed, C. Multi-Attribute Rating Method for Selecting a Clean Coal Energy Generation Technology. Energies 2021, 14, 7228. https://doi.org/10.3390/ en14217228

Academic Editor: Antonio Zuorro

Received: 13 September 2021

Accepted: 28 October 2021

Published: 2 November 2021

Publisher's Note: MDPI stays neutral with regard to jurisdictional claims in published maps and institutional affiliations.

Copyright: (c) 2021 by the authors. Licensee MDPI, Basel, Switzerland. This article is an open access article distributed under the terms and conditions of the Creative Commons Attribution (CC BY) license (https:// creativecommons.org/licenses/by/ $4.0 /)$.

\begin{abstract}
The process of technology management contains various stages, such as the identification, selection, acquisition, implementation, and maintenance of technologies. In the case of power generation companies, a key aspect of the selection stage is the choice of generation technologies for newly commissioned units. The investment decision depends on many factors, primarily economic, environmental, social, technological, and legal, and represents a complex multi-criteria problem. Currently, the decision is further complicated by the often unpredictable tightening of environmental standards, forcing the closure of conventional sources, on which many countries have so far based their energy security. The paper analyzes the problem of choosing one of the so-called clean coal technologies to be implemented in conditions of transformation of the power sector. In this paper, five selected clean coal technologies are characterized, and the SMART method is adopted to technology selection. The following technologies were considered: supercritical coal-fired power plant (with and without CCS), IGCC power plant (with and without CCS), and IGCC power plant with CCS and integrated hydrogen production. Nine practical criteria (in three main groups: environmental, technological, economic) for comparing technologies are defined, computational experiments performed, and conclusions from the research presented. The work was based on the literature study of multi-criteria decision support and an analysis of power sector needs based on the example of the Polish power sector. The conducted research, apart from the technology recommendation, led to the conclusion that the chosen method may be applied to decision-making in the field of power generation technology management. The study also indicated the potential direction of the development of a power generation structure in a situation where a component of ensuring energy security is the use of available coal fuels.
\end{abstract}

Keywords: MULTIPLE criteria analysis; SMART method; clean coal technology; decision support system; energy generation technology; technology management

\section{Introduction}

One of the first formal definitions of technology management describes it as a process that involves the development, implementation, and dissemination of technology in organizations [1]. This definition implies that technology management is a multidisciplinary process [2] that integrates engineering, scientific, and management disciplines to plan, develop, and implement technological capabilities to shape and achieve the organization's strategic and operational objectives [1]. The basic model of the technology management process, according to [3], includes the following stages: (1) Identification, (2) Selection/Election, (3) Acquisition, (4) Implementation and Operation, (5) Maintenance and Support. Researchers in the discipline, such as [4-7], attempt to identify the methods and practices used in the various stages of the technology management process, based on the models developed by $[3,8]$. Technology, knowledge, and innovation management activities are driven by the global competition among companies [9]. However, increasing competitiveness is not the only driver for strategic technology planning. Depending on the 
industry and type of organization, technology management is also influenced by market demands, regulations, technological changes, and innovations in the sector [10].

The power sector is an example of an industry struggling with inevitable transformations, including technological changes. Over the past decade, the increasing trend in $\mathrm{CO}_{2}$ emissions is perceived as one of the major causes of climate change [11]. The global atmospheric carbon dioxide emissions associated with electricity and heat generation in 2020 amounted to 31.5 billion tons [12]. Because of the impact on the environment (including the deterioration of air quality), politically motivated decisions are made in view of the need for a profound energy transformation aimed at decarbonization. The road to achieving this goal leads to a change in the structure of the production systems, the utilization of different fuels, and public education. Given that technological transformation is constantly creating new challenges, but also opportunities for economic and social development, the latter should be captured and exploited through effective technology management [13].

The paper focuses on the selection of generation technology following the outlined model of technology management conditioned by the need to reduce $\mathrm{CO}_{2}$ emissions in the power system. Decision-making concerning the management of changes in power generation units (building of new units, modernization of the existing ones, decommissioning of the inefficient ones) is a multi-criteria problem. Moreover, in light of the complexity and the multiplicity of aspects related to ensuring energy security, the single-criteria (economic) analysis is no longer an efficient approach [14].

To support decision-makers, in addition to the basic rules of decision analysis based on the economic evaluation of projects, it is possible to apply an approach from the MCDM (multiple-criteria decision-making) area [15]. In terms of technologies that provide $\mathrm{CO}_{2}$ emission reductions, clean coal technologies could enter the spotlight, with the potential of coupling conventional power generation methods with distributed renewable energy sources [16-18]. For this study, a preliminary choice of decision variants was made, and the overriding selection criterion was to reduce the harmful environmental impact of conventional coal-fired power generation, as well as to achieve the required availability and flexibility of the generating sources from the point of view of system operation, comparable to the use of conventional gas-fired sources. Therefore, renewable sources such as photovoltaics and wind (limited, in supplying the required power, by the demand of the grid operator), biogas and biomass (limited fuel availability), hydropower (limited due to geophysical conditions), and nuclear power plants (with a high economic and technological entry threshold and public resistance) were left for further studies.

It is vital to emphasize that the analyzed solutions are highly advanced technologies, currently developed only in some European countries, Japan, and the United States [19]. The main objective of this paper is to assess the possibility of using multi-criteria analysis and decision analysis as tools supporting the selection stage in the process of energy technology management. There exist studies using multi-criteria methods [14,15,20-26], but the application of the SMART (Simple Multi-Attribute Rating Technique) method to investment decisions in the power sector remains little studied. In the literature, a lot of attention has been paid to the problem of the selection of energy generation technologies, especially in relation to renewable energy sources [14,27-30], as well as general planning for the sustainable development of the sector [31-34]. Despite many studies in this area, the issue of selection itself and the support to the decision concerning the selection of conventional sources and widely understood clean coal technologies is not fully resolved. Authors who address the topic of coal-based generation sources consider country-specific cases, among which publications referring to the energy sector in China dominate $[17,35-38]$. The choice of the Polish energy sector as the case study is justified, as there are few publications on the selection of coal-fired generation sources dedicated to the domestic sector [39,40]; moreover, no publications use the SMART method for this purpose.

The proposed assessment is one of the elements of the process of technology management. The practical effect is the recommendation of technology that could be adopted. The theoretical and cognitive contribution to the analyzed field is the development of a 
universal set of criteria to compare manufacturing technologies, as well as the adaptation of the SMART method to solve decision-making problems in the power sector.

The research method proposed in the paper is based on an additive model combining weighted normalized evaluations of the proposed solutions to the decision problem with respect to a set of comparison criteria. The adaptation of the SMART method to the solved research problem is based on the consideration of the market dissimilarity of the power sector, including the specific nature of power and electricity as market products and the development of various technological trends. For the research, a dedicated set of problem-oriented comparison criteria was defined, and a research scenario was proposed assuming a significant increase in the price of $\mathrm{CO}_{2}$ emission allowances as a consequence of non-market activities.

\section{Literature Review}

\subsection{Power Sector Transformation-The Case of Poland}

Since the late 1990s, the EU has set targets for developing renewable energy, improving energy efficiency, and reducing emissions of pollutants and greenhouse gases, which have been gradually met and updated [11]. The main driving force for reducing $\mathrm{CO}_{2}$ emissions under the EU policy is the shift away from carbon-based fuels and the administrative introduction of paid carbon allowances. The artificial increase in the cost of coal technologies caused by this shift stimulates the development of technologies that do not generate emissions or prevent them [41]. The regulatory mechanisms resulting from the adopted policy have a direct impact on the current and future operation of power sectors based on fossil fuels, such as the Polish power sector [42]. This impact is mainly manifested in the increase of electricity generation costs, the deterioration of the results of energy enterprises, and the impossibility of the future use of technologies employed so far [43].

The Energy Policy of Poland until 2040 (PEP2040) is the basic document setting out the framework for the energy transformation in Poland. It provides guidelines on the selection of technologies to build a low-carbon energy system, from raw material acquisition, through energy generation and supply (transmission and distribution), to the way it is used and sold [16]. The PEP2040 document is integrated with the provisions of the Paris Agreement [44], the EU climate and energy policy framework [45], and the European Green Deal [46].

Because of the limitations arising from the EU legislation, the priorities of the Polish energy policy include the guarantee of energy security, increase of competitiveness, and improvement of energy efficiency, as well as the minimization of the power sector impact on the environment [16]. One of the ways to achieve these goals is to expand the use of renewable energy, whose development in recent years has been dominated by wind (onshore wind turbines) and photovoltaic sources. The use of biogas, biomass, and hydroelectric power plants is less salient on a national scale due to limited fuel availability and generation capacity [47]. Renewable energy in the country is only a supplement to coal-based generation sources due to its unstable and dispersed nature [48].

Another way of moving to a low-carbon economy is the development of gas sources, large-scale energy storage, and the introduction of nuclear power [16,49]. However, this path requires the acquisition of technology (nuclear power), both at the stage of investment and operation (developing the competence to ensure the safe use of nuclear power) and large-scale fuel imports (natural gas imported in sufficient quantities and a reliable manner), which are significant barriers to development. An equally significant barrier is the lack of appropriate systems regulating the flexible operation of technologies in the energy market (current legal regulations treat large-scale storage as a generating unit) [50]. The rapid abandonment of coal sources is hampered by the prospect of losses in national business, social problems in coal-dependent regions, rising electricity and heat prices, concerns about ensuring energy security in the face of a growing demand for power and electricity, and a lack of long-term political decisions [51,52]. Such phenomena are currently observed in the country's economy. Ensuring safety is also related to the problem of the planned 
decommissioning of obsolete coal-fired units, which will be shut down due to the failure to meet environmental requirements and the lack of economic justification to undertake further modernization works $[48,49,53]$. Planned shutdowns must be synchronized with launching new generating units using technologies complying with the BAT conclusion, which sets the emission limit at $505 \mathrm{~g} / \mathrm{kWh}$ [54].

An attempt to find a compromise between the specifics of the Polish power sector and the requirements of the EU climate policy may be made by developing clean coal technologies (CCTs) $[17,18]$. In this case, the term refers to low- and zero-emission coal-fired units which, by guaranteeing a high energy efficiency, will reduce the emission of $\mathrm{CO}_{2}$, nitrogen oxides, and sulfur compounds to the atmosphere [55]. CCT systems can be applied at different stages of coal processing, such as preparation, combustion/gasification, removal of pollutants, and $\mathrm{CO}_{2}$ capture [19]. The development of CCT technology represents the potential to improve the efficiency of coal resource utilization while reducing harmful environmental impacts [56]. The United States and Japan were the first to make efforts to commercially develop CCT systems $[19,56]$. CCT solutions for power generation include: (i) Fuel gas cleaning technologies (desulfurization using sorbents, selective catalytic reduction, ammonia denitrification methods, chemical and physical removal of carbon dioxide); (ii) Coal combustion technologies (supercritical and ultracritical combustion, power plants with steam boilers, circulating fluidized bed boilers, combustion systems in oxygen); (iii) Coal gasification technologies (aboveground and underground gasification); (iv) Hybrid systems technologies (trigeneration, use of hydrocarbon) [55,57].

Because of the changing environment and technology development, it is not possible to unequivocally state which technologies will be most effective and guarantee a cost-effective transition to a low-carbon economy on a national scale. When building development strategies, it is important to consider how new technologies can affect capital costs and increase power flexibility and energy efficiency [58]. The decisions must be economically justified to prove applicable. While new technologies and opportunities are emerging rapidly, there is a need to analyze them carefully to assess their costs and benefits [59].

A typical approach in decision-making for new investment projects in the power sector is to focus on economic criteria analyzed from the asset owner's point of view. The measurement of the economic efficiency of the investment decision most often includes the levelized cost of energy (LCoE), net present value (NPV), and internal rate of return (IRR) [60]. In the case of technologies of an innovative nature or technologies remaining in the research stage, the decision criterion is the result achieved in the research and development programs. However, the common methodology for evaluating these programs focuses on profits and does not take into account the long-term development of innovations, where the transition from R\&D to commercialization takes a long time [61]. The ecological, social, and technological aspects of investment decisions are usually taken into account only from the perspective of potential costs, e.g., in the form of $\mathrm{CO}_{2}$ emission charges, costs of technology acquisition, or employment level during the construction and operation of a generating unit [62]. A valuable addition to the strictly quantitative approach is the use of multi-criteria decision support methods, which allow for the analysis of the problem in both qualitative and quantitative criteria [15]. The essential requirement for decisions on undertaking new investment projects in the generation sector is to cover the electricity demand and ensure adequate reserves in the power system. Consequently, it is necessary to plan for the long-term share of individual technologies in covering the demand for electric power and energy. With that in mind, at the same time, the system should have an adequate number of low-carbon conventional generating units capable of covering the instantaneous demand for electric power, together with renewable sources ensuring the required amount of renewable energy in the total balance of its consumption.

\subsection{Multi-Criteria Analysis}

In the field of MCDM, there are two main streams of research describing the decisionmaking process: the so-called French school and the American school. The French school 
primarily promotes the outranking concept for evaluating discrete alternatives [63]. The American school is based on multiple attribute value functions and multiple attribute utility theory (MAUT) [64]. Research work in MCDA (Multi-Criteria Decision Analysis) is based on several different approaches to assist decision-makers in their attempts to identify a preferred alternative, classify it and/or rank it. F.A. Lootsma divides the MCDM approach into four categories: (i) descriptive approach, (ii) prescriptive approach, (iii) prospective approach, (iv) constructive approach [65]. B. Roy distinguishes three families of MCDM: (i) single criterion synthesis approach; (ii) outranking approach; and (iii) interactive local study approach [63]. On the other hand, P. Vincke calls them, respectively, (i) multi-attribute utility theory, (ii) outranking methods, and (iii) interactive methods [66]. The subject of the classification and characterization of multi-criteria decision analysis methods is further developed in other papers $[20,67,68]$.

Many terms are used in the literature to refer to multiple-criteria decision-making, including Multi-Criteria Decision Analysis, Multi-Objective Decision-Making (MODM), Multi-Attributes Decision-Making (MADM), and Multi-Dimensions Decision-Making (MDDM) [67]. MCDM is a tool used to find solutions to a wide range of economic, manufacturing, military, and construction issues, where it plays an important role in making investment decisions, evaluating projects, and assessing economic benefits [69]. Overviews of applications of MCDM methods to solve multiple problems are referenced in [22,70]. The MCDM methods are also applied in decision support in the energy sector. In the literature, the subject of investment decision support in the energy sector is addressed by $[14,15,20-26]$. The main ideas of the researchers are focused on the formulation of criteria for the evaluation of energy generation technologies and the construction and evaluation of methods supporting the mentioned decision-making processes. The methods used by researchers include multi-attribute utility theory (MAUT), analytic hierarchy process (AHP), analytic network process (ANP), preference ranking organization method for enrichment evaluations (PROMETHEE), and elimination and choice expressing reality (ELECTRE).

Multi-criteria decision-making (MCDM) is a systematic approach to evaluate possible alternatives by combining inputs with information about benefits / costs and opinions of decision-makers (DMs) or stakeholders [22]. The main objective of MCDM is to provide decision-makers with a tool that enables them to solve a multi-criteria decision problem in which several and often conflicting issues must be considered [24,67]. The multi-criteria approach is used to identify and quantify decision-makers' preferences over many factors to evaluate alternatives [20]. The overall evaluation consists of some criteria relevant to the problem at hand. This evaluation may take the form of selecting a preferred alternative, ranking alternatives, or sorting alternatives into ordered classes. The set of alternatives can be either explicitly defined and quantified, or implicitly defined by constraints specified through mathematical programming. The criteria can be specified in general terms, but each criterion should be associated with a measurable characteristic that provides a quantitative or qualitative scale for evaluating the alternatives to solve the decision problem [71].

The MCDM approach typically requires the following inputs: scores on several dimensions associated with different alternatives and outcomes, and weights associated with trade-offs along these dimensions. These weights play a fundamental role in measuring overall preferences for alternatives. The basic approach of MCDM is to calculate the total score for an alternative as a linearly weighted sum of its scores across several criteria [22,67]. A literature review identified the following classification of MCDM: (i) multiple attribute theory; (ii) positional-norming methods; (iii) interactive methods [24]. In multiple attribute theory, the decision-maker's preference for an alternative is determined by fixed criteria. The estimated utility value based on the additive model generates a score for each alternative. Some of the methods of this approach include MAUT, SMART, and AHP.

In positioning methods, the preferences of decision-makers are represented by binarrative relationships between alternatives concerning the criteria. Examples of such methods are ELECTRE and PROMETHÉE. The essence of the interactive approach is multi-objective linear programming. Results are obtained by aggregating the preferences of 
decision-makers after mathematical calculations, interactively and successively evaluating these solutions, and possibly changing the preference structure in the face of newly available information. The methods of this approach are STEM, TRIMAP, ICW, and PARETO RACE [24]. The MCDM approaches share some common mathematical elements: values for the alternatives are assigned to each criterion, then multiplied by appropriate weights and combined to obtain a total score. Multi-criteria methods differ primarily in the scheme through which the criteria values are assigned and combined (for each attribute and the overall score) $[21,22,71]$.

\section{Method}

Decision-making in the selection of electric power generation technology is a complex process. Due to the scope of the process, the decision cannot be based solely on a financial analysis. A natural approach is to support the decision-making process by applying the MCDM approach. The method selected for the study should meet the basic requirements, i.e.: (i) take into account the multi-criteria nature of the problem, (ii) take into account the preferences of the decision-maker, (iii) encompass a simple algorithm, (iv) be adaptable to the specifics of the research problem.

The Simple Multi-Attribute Rating Technique (SMART) [72] was chosen from among the methods of the MCDM family that meet the listed requirements. It is a multi-criteria technique for supporting complex decision-making processes. The method is based on a linear additive model that allows the evaluation of decision options concerning qualitative and quantitative criteria [73]. The process of solving a decision problem can be divided into three main phases: (i) the preparation phase, including the definition of the research problem, the identification of decision-makers, the creation of solution variants, and a set of comparison criteria (construction of the backbone of the decision matrix), (ii) the evaluation phase, i.e., the evaluation of variants against the criteria and the allocation of weights to the criteria (completion of the decision matrix), (iii) the decision phase, making a preliminary decision and conducting a sensitivity analysis. The outline of the decision-making process is shown in Figure 1 [25].

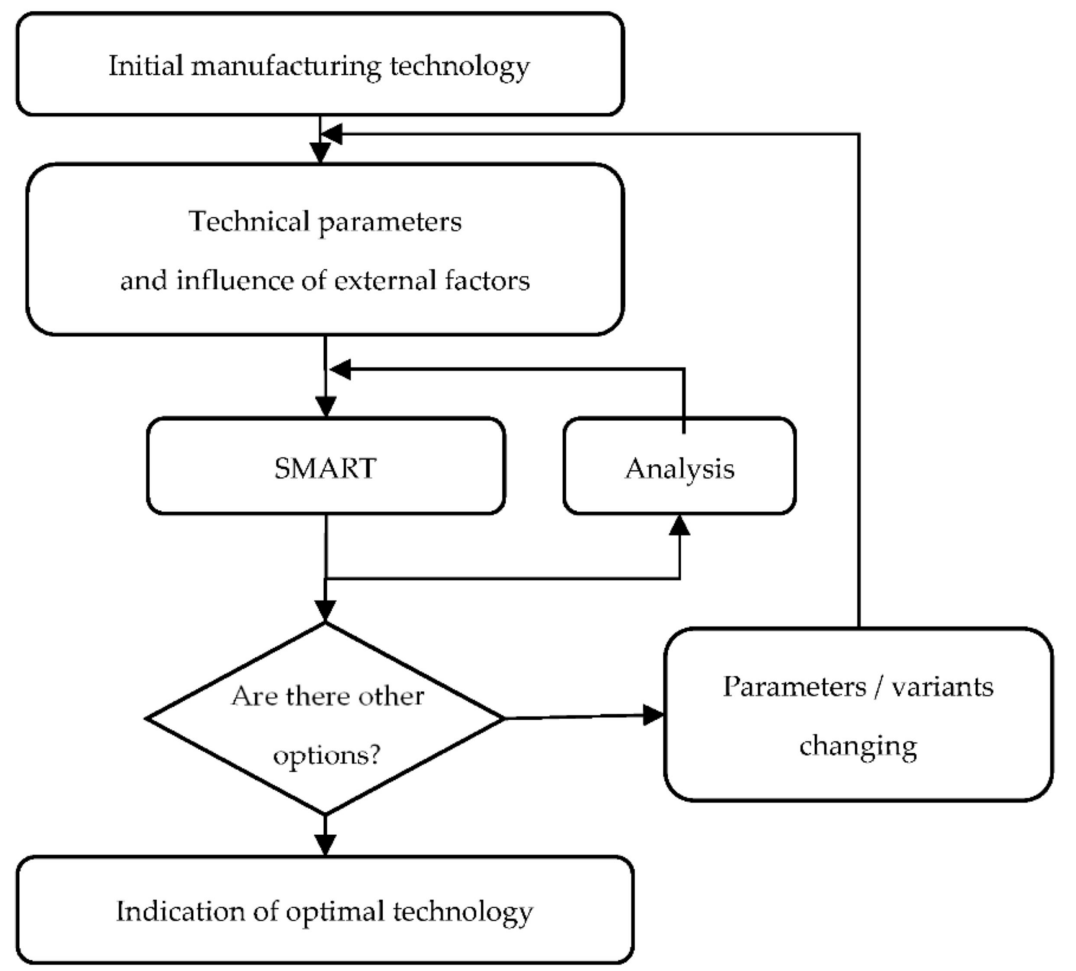

Figure 1. Decision-making process (source: own study). 
The SMART method consists of eight steps:

- $\quad$ Step 1: Problem and decision-maker identification

- $\quad$ Step 2: Identification of alternatives

- $\quad$ Step 3: Decision criteria determination

- $\quad$ Step 4: Assigning values to the criteria for each alternative

- $\quad$ Step 5: Determining the weights of the decision criteria

- $\quad$ Step 6: Calculating the weighted average values assigned to each alternative

- $\quad$ Step 7: Preliminary decision-making

- Step 8: Sensitivity analysis performing

The functional model used in the SMART method is as follows [74]:

$$
U\left(a_{i}\right)=\sum_{j=1}^{m} W_{j} u_{j}\left(a_{i}\right),
$$

where:

$j$-index of the criterion, $j=1, \ldots, m$

$i$-index of the alternative, $i=1, \ldots, n$

$m$-number of criteria

$n$-number of alternatives

$W_{j}$ - fixed weight assigned to the criterion

$a_{i}$ - decision variant $i$ (alternative)

$u_{j}\left(a_{i}\right)$-evaluation of variant $a_{i}$ with respect to criterion $j$

$U\left(a_{i}\right)$-the final value of alternative $i$

\subsection{Identification of the Problem and Decision-Maker}

The first step in applying the SMART method or any other technique from the MCDM family is to establish a common understanding of the decision context, problem identification, and decision actors. The SMART method relies on input from decision-makers to establish a relative familiarity with the various attributes of the proposed solutions. Decision-makers bring subjective opinions and industry knowledge to the process. Based on the knowledge and opinions of the decision-makers, the impact of the more important attributes is emphasized while the influence of the secondary criteria is reduced, when evaluating the overall utility of the solution [23]. The SMART method can be used both by individuals and for decision-making at the organizational level in companies and public institutions. At this step, it is necessary to define the decision problem.

\subsection{Identification of Alternatives}

At this step, decision alternatives are identified. The set of alternatives depends directly on the decision problem posed. Although a large number of alternatives can be proposed for the choice of generating unit technology, not all of them meet the basic requirements defined by the decision-maker, often depending on the economic realities of the country.

\subsection{Decision Criteria Determination}

Decision criteria (decision attributes) are applied to compare alternative solutions. It is recommended to reduce the set of attributes to a sufficient minimum of items, taking the particular emphasis to ensure their mutual independence [75]. Defining the set of comparison criteria completes the first phase of the SMART method (preparation phase) and allows one to build the framework of the decision matrix $V$, where the columns 
correspond to the criteria $(C 1, \ldots, C m)$ and the rows to the solution alternatives $(A 1, \ldots$, $A n)$ [76]. The decision matrix $V$ is as follows:

$$
\begin{gathered}
V=\begin{array}{c}
A_{1} \\
A_{2} \\
\ldots \\
A_{n}
\end{array}\left[\begin{array}{rrrr}
C_{1} & C_{2} & \ldots & C_{m} \\
\ldots & \ldots & \ldots & \ldots \\
\ldots & \ldots & \ldots & \ldots \\
\ldots & \ldots & \ldots & \ldots \\
\ldots & \ldots & \ldots & \ldots
\end{array}\right] \\
V-\text { decision matrix }
\end{gathered}
$$

The proposed set of decision criteria complies with the overall objective and the primary expectations of the decision-maker. The decision-maker is looking for the solution that will provide the greatest benefit at the lowest cost, so the comparison criteria are divided into two main groups: project inputs and project outputs. Project inputs represent contributions to the project in terms of financial, material, and knowledge resources. Project outputs represent results and impacts associated with a project. The scope of the comparison criteria must not exceed the competence of the decision-maker. The initial screening of a set of criteria consists of an assessment of the feasibility of evaluating the alternatives without exceeding the competence of the decision-maker. As a result, the criteria requiring specialized analysis, going beyond the scope of the research, and those of low significance will be omitted. The former are the criteria of legal and social conditions, which require legal and sociological analyses. Finally, limiting the number of criteria simplifies the application of the SMART method.

\subsection{Assigning Values to the Criteria for Each Alternative}

The structure imposed by the SMART method of conducting the decision-making process divides the problem into its distinctive parts. In this way, each decision alternative is evaluated against each of the comparative criteria. The evaluation of alternatives for attributes takes two forms: direct evaluation, for attributes that cannot be evaluated quantitatively, and value functions, for attributes that can be expressed as quantifiable variables. The procedure scheme for direct evaluation is the following: (i) ranking the variants of solutions for a given attribute by placing the most desirable alternative first, (ii) assigning the maximum value of the scale to the first item and the minimum value to the last one (the adopted evaluation scale values from 0 to 100), (iii) ranking the remaining options in terms of the least and the most favorable position. In the case of quantitative criteria, the basis of the rating system are value functions based on the bisecting method and trend line determination. At this stage, the decision matrix $V$ is supplemented with the solution assessments as follows:

$$
V=\left[\begin{array}{cccc}
u_{1}\left(a_{1}\right) & u_{2}\left(a_{1}\right) & \ldots & u_{m}\left(a_{1}\right) \\
u_{1}\left(a_{2}\right) & u_{2}\left(a_{2}\right) & \ldots & u_{m}\left(a_{2}\right) \\
\ldots & \ldots & \\
u_{1}\left(a_{n}\right) & u_{2}\left(a_{n}\right) & \ldots & u_{m}\left(a_{n}\right)
\end{array}\right]
$$

\subsection{Determining the Weights of the Decision Criteria}

In the SMART method, the weights are usually assigned to the criteria by the decisionmakers, based on their own experiences, knowledge, and perceptions. The assigned weights allow them to rank the decision attributes by the importance of the problem [76]. The problem of such a solution may be the inconsistency in the subjective assignment of weights by decision-makers. To reduce the occurrence of possible discrepancies, spanning weights are assigned to the criteria. The criteria valuation method is based on comparing the impact of changes, from the least to the most favorable value, on the overall evaluation of the solution. In this way, each decision attribute is objectively described with a numerical scale. The criterion ranked the first among all attributes is assigned 100 points, while the weights of the remaining criteria are determined by juxtaposition. The change from the 
worst to the best value in criterion one is compared with the change in criterion two. This procedure is repeated for all attributes. The last step is to normalize the values of the assigned weights, the sum of which should converge to 100 . The normalization formula is as follows:

$$
W_{j}=\frac{w_{j}}{\sum_{k=1}^{m} w_{k}} * 100, \forall j
$$

where:

$W_{j}$-normalized weight of the decision criterion $j$,

$w_{j}$ - the weight assigned to a decision criterion $j$,

$\sum_{k=1}^{m} w_{k}$-the sum of the weights assigned to all the criteria.

The higher-order attribute weights are determined by summing the sub-criteria weights of the vector $W[76]$.

\subsection{Calculating the Weighted Average Values Assigned to Each Alternative}

The overall evaluation of the decision options is determined using the function model of the SMART method (1). The applied additive model relies on the summation of the weighted scores of individual decision alternatives against the comparison criteria. The resulting weighted averages allow us to rank the alternatives in order of importance. At the end of this step, the overall score for each alternative represents not only the ratings of the alternatives against the criteria but also the weights that are assigned to each criterion. The overall score formula is as follows:

$$
\begin{gathered}
U=V \times W=\left[\begin{array}{cccc}
u_{1}\left(a_{1}\right) & u_{2}\left(a_{1}\right) & \ldots & u_{m}\left(a_{1}\right) \\
u_{1}\left(a_{2}\right) & u_{2}\left(a_{2}\right) & \ldots & u_{m}\left(a_{2}\right) \\
\ldots & \ldots & u_{m} \\
u_{1}\left(a_{n}\right) & u_{2}\left(a_{n}\right) & \ldots & u_{m}\left(a_{n}\right)
\end{array}\right] \times\left[\begin{array}{c}
W_{1} \\
W_{2} \\
\ldots \\
W_{m}
\end{array}\right]=\left[\begin{array}{c}
\sum_{i=1}^{m} W_{i} u_{i}\left(a_{1}\right) \\
\sum_{i=1}^{m} W_{i} u_{i}\left(a_{2}\right) \\
\ldots \\
\sum_{i=1}^{m} W_{i} u_{i}\left(a_{n}\right)
\end{array}\right] \\
=\left[\begin{array}{c}
U\left(a_{1}\right) \\
U\left(a_{2}\right) \\
\ldots \\
U\left(a_{n}\right)
\end{array}\right] \\
\text { W- vector of normalized weights of decision criteria } \\
\text { /vector of overall evaluation scores }
\end{gathered}
$$

The weighted scores assigned to each option are rescaled:

$$
U^{\prime}\left(\mathrm{a}_{\mathrm{i}}\right)=\frac{U\left(a_{i}\right) * 100}{U_{\max }}
$$

where: $U_{\max }$ - the maximum value for the aspiration variant, which would be scored out of 100 in all criteria.

\subsection{Preliminary Decision-Making}

The next step in the process is to summarize the information contained in the decision matrix. The aggregated ratings form the matrix of the overall rating of the alternatives against the main categories of comparison criteria. The obtained ratings allow for further comparisons of the alternatives, their classification, and a preliminary decision. The selection of the best decision-making variant requires the analysis of the obtained results and finding an optimal compromise between the defined groups of criteria. To illustrate the interdependence of the criteria, the obtained results are plotted on a graph, and then the efficiency limit is drawn through the points corresponding to dominant variants. The effectiveness frontier connects the decision variants offering the highest value of effects for a given input to the project (or the lowest input for a given level of effects) [77]. 
The project inputs and the outputs at this stage of the analysis are expressed in a numerical scale, the best variants being those that have the highest values of the ratings determined in the previous step of the SMART method. The ratings of the alternatives against the decision criteria are scaled so that one point on the effect scale is equivalent to one point on the contribution scale. The choice between options on the effectiveness frontier depends on the preferences of the decision-makers. Narrowing the proposed solutions to those on the efficiency frontier can facilitate the decision-making process. While it may prove insufficient to identify the single best solution, it nonetheless allows for a better look at the problem. In the case of the pre-preferred solution not lying on the efficiency frontier, the data and sub-option evaluations should be re-examined to find the weak points of the solution and eliminate them.

\subsection{Sensitivity Analysis Performing}

The final step of the SMART method is a sensitivity analysis. The task of the analysis is to conclude on the reliability of the obtained results. Taking into account the fact that some stages of the SMART method are characterized by a high degree of subjectivity, a sensitivity analysis is conducted for the comparison criteria of greatest importance to the decision-maker. A test of the sensitivity of the ratings of the decision options to the changes in the weights assigned to the comparison criteria is designed to check whether the results of the decision analysis remain robust to change and are not unduly distorted.

\section{Results}

\subsection{Identification of the Problem and Decision-Maker}

The research was conducted for the problem of CCT technology selection under the conditions of the Polish power system. The decision-makers were defined as the managers of an energy company. The decision-makers have knowledge and competencies regarding the operation of the power sector, the technologies used, and the financing of investment projects. The purpose of the decision-makers is to analyze the variants of generation plants with an indication of the potential direction of action.

\subsection{Identification of Alternatives}

Five alternative technologies were selected for the study, as shown in Table 1 . The selection of the analyzed technologies was influenced, among other things, by the projects of new supercritical coal-fired power units completed in recent years in the Polish power sector, as well as by the trends observed in the global economy. The information on individual technologies was obtained from the IEAGHG report of the International Energy Agency [78]. The document prepared by IEAGHG contains a comprehensive set of data concerning technological parameters and cost aspects of the analyzed decision alternatives. The set of alternatives meets certain conditions: (i) net electricity output above $800 \mathrm{MW}$ (except in the case of cogeneration of electricity and hydrogen), (ii) $\mathrm{CO}_{2}$ emissions for CCS-equipped units below $100 \mathrm{~kg} / \mathrm{MWh}$, (iii) fuel flow rate below $350 \mathrm{t} / \mathrm{h}$. Tables 2 and 3 present the characteristics of the decision options.

Table 1. Solution options.

\begin{tabular}{cc}
\hline Variant & Technology \\
\hline A1 & Supercritical coal-fired power plant \\
A2 & Supercritical coal-fired power plant with CCS ${ }^{1}$ \\
A3 & IGCC ${ }^{2}$ power plant \\
A4 & IGCC power plant with CCS \\
A5 & Polygeneration: IGCC power plant with CCS and \\
& integrated hydrogen production \\
\hline
\end{tabular}

\footnotetext{
${ }^{1}$ CCS—carbon capture and storage. ${ }^{2}$ IGCC —integrated gasification combined cycle.
} 
Table 2. Characteristics of the decision options.

\begin{tabular}{ccccccc}
\hline & Unit & A1 & A2 & A3 & A4 & A5 \\
\hline Fuel flow rate & $\mathrm{t} / \mathrm{h}$ & 325.00 & 325.00 & 314.90 & 314.90 & 349.10 \\
Net power output & $\mathrm{MW}$ & 1029.60 & 822.40 & 100.53 & 804.00 & 447.60 \\
Auxiliary power consumption & $\mathrm{MW}$ & 47.10 & 135.70 & 90.72 & 259.20 & 237.70 \\
$\mathrm{CO}_{2}$ emissions & $\mathrm{kg} / \mathrm{MWh}$ & 745.80 & 93.00 & 695.36 & 92.60 & 93.70 \\
$\mathrm{NO}_{\mathbf{x}}$ emissions & $\mathrm{kg} / \mathrm{MWh}$ & 0.43 & 0.54 & 0.33 & 0.33 & 0.16 \\
$\mathrm{SO}_{\mathrm{x}}$ emissions & $\mathrm{kg} / \mathrm{MWh}$ & 0.43 & 0.01 & 0.01 & 0.01 & 0 \\
$\mathrm{CO}_{2}$ captured & $\%$ & 0 & 90.10 & 0 & 90.10 & 90.10 \\
$\mathrm{CO}_{2}$ emitted & $\mathrm{t} / \mathrm{h}$ & 767.40 & 76.50 & 747.70 & 74.50 & 91.90 \\
$\mathrm{CO}_{2}$ stored & $\mathrm{t} / \mathrm{h}$ & 0 & 690.90 & 0 & 673.20 & 737.90 \\
Power plant utilization rate & $\%$ & 90 & 90 & 85 & 85 & 85 \\
\hline
\end{tabular}

Table 3. Capital expenditures and operating costs of the decision alternatives.

\begin{tabular}{ccccccc}
\hline & Unit & A1 & A2 & A3 & A4 & A5 \\
\hline Total capital expenditures & Mln EUR & 1490.00 & 2279.00 & 2448.95 & 2538.00 & 2461.00 \\
Cost per 1 kW of installed capacity & EUR/kW & 1447.16 & 2771.16 & 2433.07 & 3156.72 & 5498.21 \\
Operating and maintenance expenses & Mln EUR/year & 22.35 & 34.19 & 61.22 & 63.45 & 61.53 \\
Unit cost of electricity generation & EUR/ MWh & 59.24 & 76.74 & 82.56 & 92.78 & 177.79 \\
\hline
\end{tabular}

Variant A1 is the most conservative one. It is a coal-fired power plant using supercritical steam technology. This solution assumes the attainment of a higher efficiency while using less power raw material and, consequently, lower carbon dioxide emissions per unit of power produced. The A2 solution extends the A1 variant by adding carbon capture, transport, and storage installation, thus reducing carbon dioxide emissions (CCS installation). Variant A3 is a gas-steam power plant with integrated oxygen gasification of the coal cycle. The IGCC technology is characterized by lower sulfur, nitrogen, and carbon dioxide emissions due to the purification of the syngas before it enters the combustion chamber. Option A4 is an extension of A3, with CCS added. Alternative A5 involves the cogeneration of electricity and hydrogen. This variant is highly innovative, and the produced hydrogen sets the direction for development and is also a potential source of revenue. This option has all the functionalities of an IGCC power plant and CCS installation.

\subsection{Decision Criteria Determination}

In the first approach, the decision criteria database was developed based on a literature review. The set of attributes included specifically formulated, independent, and non-overlapping criteria divided into two main categories: project inputs and project outputs. Among them were attributes belonging to the groups of environmental, technological, social, legal, financial, and economic factors. The set of proposed attributes, after preliminary verification, was limited to the nine relevant to the sustainability of the portfolio structure of the decision-making entity. As regards the input criteria, the following were considered: (C1) Amount of capital expenditure, (C2) Unit cost of electricity generation, (C3) Cost of purchase of $\mathrm{CO}_{2}$ emission allowances, (C4) Knowledge of technology, (C5) Raw material demand. The output criteria were (C6) Generation capacity, (C7) Availability of capacity, (C8), Profitability of the investment project, (C9) Development perspective. They characterize investment projects related to the commissioning of new generating units in economic, environmental, and technological terms.

Attribute $\mathrm{C} 1$ includes capital requirements. For the purpose of the analysis, it was assumed that the decision-makers can obtain sufficient funds to undertake the investments. The source of the funds for investment (own funds, loans, national and EU investment and development programs) does not affect the results of the analysis carried out in the framework of the SMART method. Attribute C2 is the unit cost of electricity generation expressed by the LCoE formula, which considers capital expenditures, operating costs, and 
the discount rate, allowing for an average comparison of different generation technologies. The determination of the LCOE requires specific assumptions to be made for each technology regarding, among other things, the amount of energy produced. For this reason, this is a point-based indicator, reflecting the assumed performance of the technology. Changes in its value depending on the assumptions made are non-linear and only partially continuous. Attribute C3 takes into account the significant share of expenses related to environmental protection in the costs of power plant operation through the purchase costs of $\mathrm{CO}_{2}$ emission allowances. Attribute $\mathrm{C} 4$ determines the knowledge of technology, the lack of which may contribute to the failure of the investment. Attribute $\mathrm{C} 5$ is the demand for raw material, which is associated with the need to ensure a stable fuel supply. Attributes C6 and C7 relate to energy security. These attributes analyze the capacity and availability of the generating unit, i.e., the percentage of time during the year when the power plant is expected to be fully operational. Attribute $\mathrm{C} 8$ refers to the profitability of the investment as determined by the NPV and payback period. Attribute $\mathrm{C} 9$ relates to the technological conditions, to examine whether a given technology creates conditions for development, e.g., in terms of the cogeneration or commercial use of by-products.

\subsection{Assigning Values to the Criteria for Each Alternative}

As an adaptation of the SMART method to the conditions of the problem, three scenarios reflecting changing conditions in the energy sector and the economic environment were initially analyzed. Scenario no. 1 envisages an increase in purchase prices of $\mathrm{CO}_{2}$ emission allowances to $80 \mathrm{EUR} / \mathrm{t}$ in $2050[78,79]$, undisturbed access to raw materials on the local market at an acceptable price, and an increase in electricity prices. To determine the trend of price changes, data from the previous 10 years provided by relevant institutions of the national and international sector were used [80,81]. Scenario no. 2 is a pessimistic one, that assumes a sharp increase in $\mathrm{CO}_{2}$ emission allowance purchase prices, difficult availability of raw materials, and the impossibility of reproducing these factors in electricity price increases. Scenario no.3 is optimistic and assumes constant purchase prices of $\mathrm{CO}_{2}$ emission allowances and a constant increase in electricity prices, but at a slower rate than assumed in current forecasts. For the study, Scenario no.1 was adopted as a reference, because, in the authors' opinion, its components remain in equilibrium.

The decision matrix $V$ consists of the five energy production technologies selected for analysis, the nine criteria characterizing these alternatives, and the ratings of the alternatives against the criteria. Table 4 presents the evaluation of the decision variants.

Table 4. Evaluated variants.

\begin{tabular}{cccccc}
\hline Criteria & A1 & A2 & A3 & A4 & A5 \\
\hline C1 & 100 & 56.93 & 66.78 & 47.08 & 0 \\
C2 & 100 & 77.57 & 70.86 & 60.15 & 0 \\
C3 & 0 & 98.09 & 6.82 & 100 & 87.63 \\
C4 & 100 & 70 & 60 & 60 & 0 \\
C5 & 67.88 & 67.88 & 100 & 100 & 0 \\
C6 & 100 & 70.52 & 87.92 & 37.33 & 0 \\
C7 & 100 & 100 & 0 & 0 & 0 \\
C8 & 85.34 & 93.34 & 0 & 52.37 & 100 \\
C9 & 50 & 0 & 100 & 100 & 100 \\
\hline
\end{tabular}

\subsection{Determining the Weights of the Decision Criteria}

The maximum weights were assigned to the following attributes (Tables 5 and 6): Size of investment expenditures (C1) and Profitability of investment project (C8). As already mentioned, the set of criteria adopted was subject to a preliminary analysis and selection, and therefore only attributes with weights greater than or equal to 50 points (wi) were included in the list (Tables 2 and 3). In general, these weights should be a measure of the preferences of managers who make decisions about the implementation of investment 
projects, in relation to particular criteria. In the conducted study, the order and values of the weights assigned to the input criteria were determined based on the authors' knowledge and experience.

Table 5. Weights assigned to the inputs.

\begin{tabular}{ccccc}
\hline Rank & & Project Inputs & $\boldsymbol{w}_{\boldsymbol{i}}$ & $\boldsymbol{W}_{\boldsymbol{j}}$ \\
\hline 1 & $\mathrm{C} 1$ & Amount of capital expenditures & 100 & 25 \\
2 & $\mathrm{C} 3$ & Cost of purchasing CO $\mathrm{CO}_{2}$ emission allowances & 90 & 23 \\
3 & $\mathrm{C} 2$ & The unit cost of electricity generation & 80 & 20 \\
4 & $\mathrm{C} 5$ & Raw material demand & 70 & 18 \\
5 & $\mathrm{C} 4$ & Knowledge of technology & 60 & 15 \\
\hline
\end{tabular}

Table 6. Weights assigned to the outputs.

\begin{tabular}{ccccc}
\hline Rank & & Project Outputs & $\boldsymbol{w}_{\boldsymbol{i}}$ & $\boldsymbol{W}_{\boldsymbol{j}}$ \\
\hline 1 & C8 & Profitability of the investment project & 100 & 29 \\
2 & C6 & Generation capacity & 90 & 26 \\
3 & C7 & Capacity availability & 80 & 24 \\
4 & C9 & Development perspective & 70 & 21 \\
\hline
\end{tabular}

\subsection{Calculating the Weighted Average Values Assigned to Each Alternative}

The weighted averages of the scores assigned to each option are presented in Table 7, below.

Table 7. Classification of decision-making options under the criteria of Project Inputs and Project Outputs.

\begin{tabular}{|c|c|c|c|c|c|c|c|c|c|c|c|}
\hline \multirow{2}{*}{ Criteria } & \multirow{2}{*}{$\mathbf{W j}$} & \multicolumn{2}{|c|}{ A1 } & \multicolumn{2}{|c|}{ A2 } & \multicolumn{2}{|c|}{ A3 } & \multicolumn{2}{|c|}{ A4 } & \multicolumn{2}{|c|}{ A5 } \\
\hline & & $u_{j}\left(a_{i}\right)$ & $W_{j^{*}} u_{j}\left(a_{i}\right)$ & $u_{j}\left(a_{i}\right)$ & $W_{j^{*}} u_{j}\left(a_{i}\right)_{j}$ & $u_{j}\left(a_{i}\right)$ & $W_{j^{*}} u_{j}\left(a_{i}\right)_{j}$ & $u_{j}\left(a_{i}\right)$ & $W_{j *} u_{j}\left(a_{i}\right)$ & $u_{j}\left(a_{i}\right)$ & $W_{j^{*}} u_{j}\left(a_{i}\right)$ \\
\hline $\mathrm{C} 1$ & 25 & 100 & 2500 & 56.93 & 1423 & 66.78 & 1670 & 47.08 & 1177 & 0 & 0 \\
\hline C2 & 20 & 100 & 2000 & 77.57 & 1551 & 70.86 & 1417 & 60.15 & 1203 & 0 & 0 \\
\hline C3 & 23 & 0 & 0 & 98.09 & 2257 & 6.82 & 157 & 100 & 2300 & 87.63 & 2015 \\
\hline $\mathrm{C} 4$ & 15 & 100 & 1500 & 70 & 1050 & 60 & 900 & 60 & 900 & 0 & 0 \\
\hline $\mathrm{C} 5$ & 18 & 67.88 & 1222 & 67.88 & 1222 & 100 & 1800 & 100 & 1800 & 0 & 0 \\
\hline \multicolumn{2}{|c|}{ Inputs $U\left(a_{i}\right)$} & \multicolumn{2}{|c|}{7222} & \multicolumn{2}{|c|}{7503} & \multicolumn{2}{|c|}{5944} & \multicolumn{2}{|c|}{7380} & \multicolumn{2}{|c|}{2015} \\
\hline C6 & 26 & 100 & 2600 & 70.52 & 1834 & 88 & 2288 & 37.33 & 971 & 0 & 0 \\
\hline C7 & 24 & 100 & 2400 & 100 & 2400 & 0 & 0 & 0 & 0 & 0 & \\
\hline C8 & 29 & 85.34 & 2475 & 93.34 & 2707 & 0 & 0 & 52.37 & 1519 & 100 & 2900 \\
\hline C9 & 21 & 50 & 1050 & 0 & 0 & 100 & 2100 & 100 & 2100 & 100 & 2100 \\
\hline \multicolumn{2}{|c|}{ Outputs $U\left(a_{i}\right)$} & \multicolumn{2}{|c|}{8525} & \multicolumn{2}{|c|}{6941} & \multicolumn{2}{|c|}{4388} & \multicolumn{2}{|c|}{4590} & \multicolumn{2}{|c|}{5000} \\
\hline
\end{tabular}

The number values of Inputs and Outputs were determined based on Equation (1). The weighted scores assigned to each option were rescaled. Rescaled scores are presented in Table 8, below.

Table 8. Assessment of decision-making options.

\begin{tabular}{cccccc}
\hline Score & A1 & A2 & A3 & A4 & A5 \\
\hline Inputs $U^{\prime}\left(\mathrm{a}_{\mathrm{i}}\right)$ & 72.22 & 75.03 & 59.44 & 73.80 & 20.15 \\
Outputs $U^{\prime}\left(\mathrm{a}_{\mathrm{i}}\right)$ & 85.25 & 69.41 & 43.88 & 45.90 & 50.00 \\
\hline
\end{tabular}

\subsection{Preliminary Decision-Making}

The results of the assessment of alternatives in categories covering financial, economic, technological, environmental, and safety aspects, presented quantitatively, are presented in the chart of Figure 2. The scale on the graph reflects the rating of each option against two groups of criteria. Both in terms of project inputs and project outputs, it was assumed that the better the solution, the more points it received. Higher values on the input scale mean 
less contribution to the project, higher values on the output scale mean more favorable results and impacts associated with the project. Solutions A1 and A2 are the dominant variants, both lying on the efficiency frontier. The options identified as dominant are characterized by the highest level of benefits to the input required for the project. Thus, options A1 and A2 achieve higher project benefits (expressed through the output group criteria) with a lower project contribution (input group criteria) than options A3, A4, and A5.

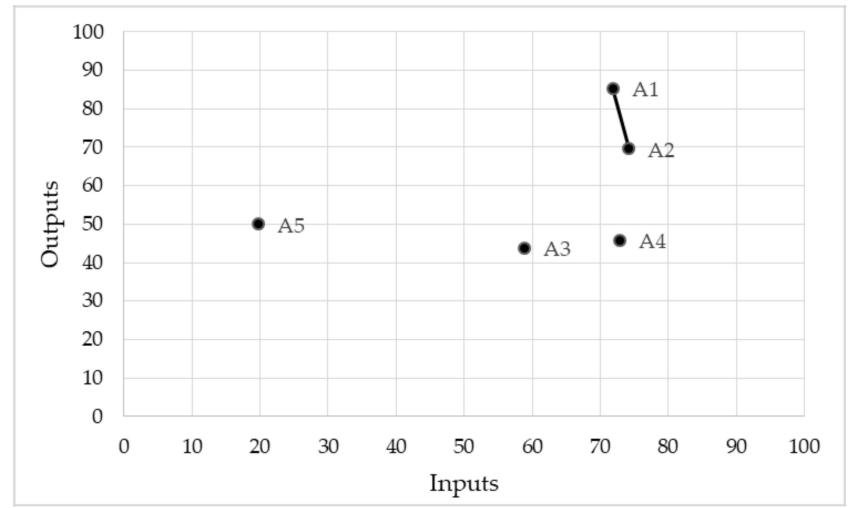

Figure 2. Efficiency frontier.

\subsection{Sensitivity Analysis Performance}

The sensitivity analysis in the study covers the attributes: $\mathrm{C} 1$ Amount of capital expenditure, $\mathrm{C} 3$ Cost of purchasing $\mathrm{CO}_{2}$ emission allowances, $\mathrm{C} 8$ Profitability of the investment project, C6 Generation capacity. The analyzed attributes include the criteria assessed as the most relevant from the decision-makers' point of view.

The chart in Figure 3 presents the sensitivity analysis of the overall ratings of each alternative against the scope of weights of the decision criteria. The weights assigned to the criteria were changed in the range from 0 to 100 in steps of 10 while keeping the values of the weights for the other criteria constant. For each of the analyzed weight values assigned to a given criterion, an overall assessment of the variant was made based on Equation (1). The overall assessment was then scaled using Equation (6) and plotted on the graph. The vertical axis corresponds to the numerical value of the variants' assessment relative to the criteria of the input or output group, depending on the examined criterion. The horizontal axis corresponds to the values of weights assigned to the criterion with the indication of the weight adopted in the conducted research. The criteria weight adopted in the conducted research is marked on the charts as the current weight.

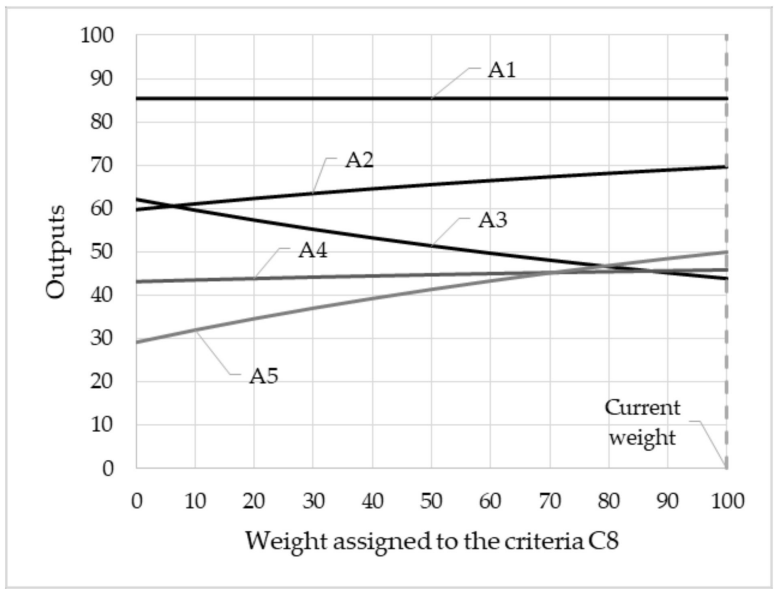

(a)

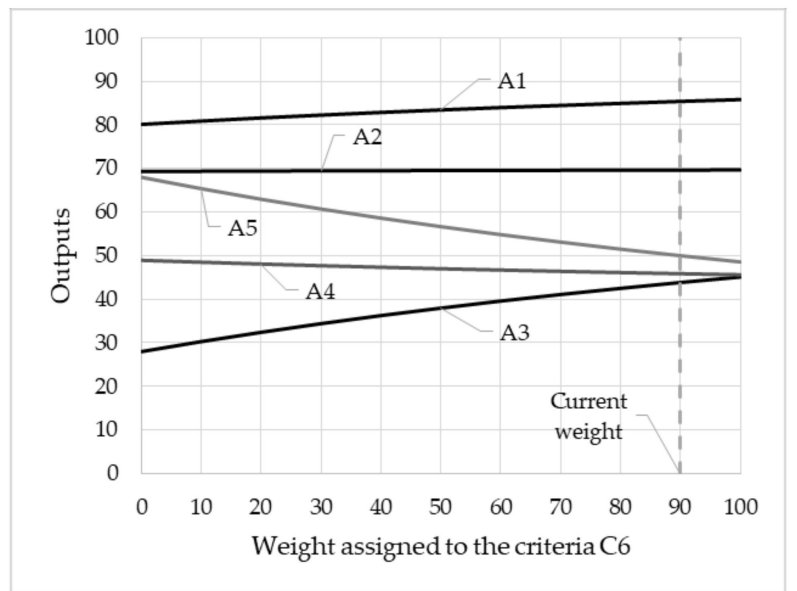

(b)

Figure 3. Cont. 


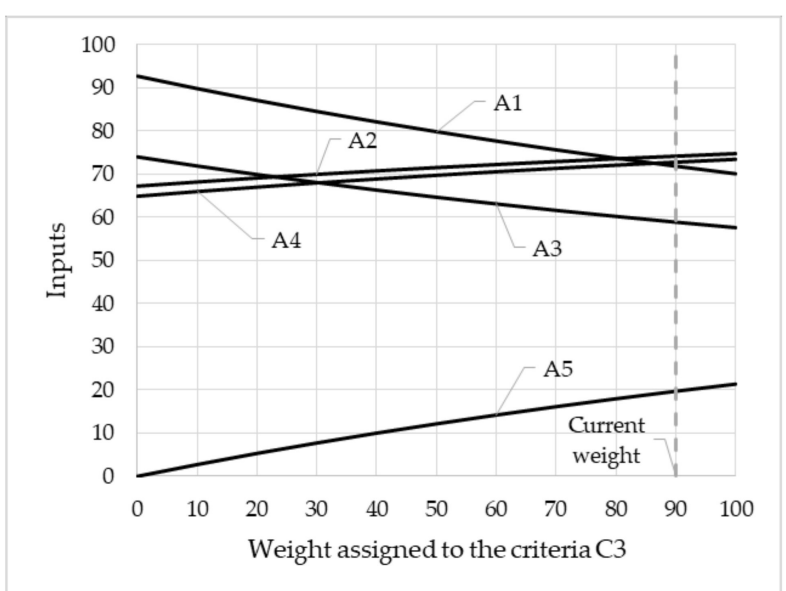

(c)

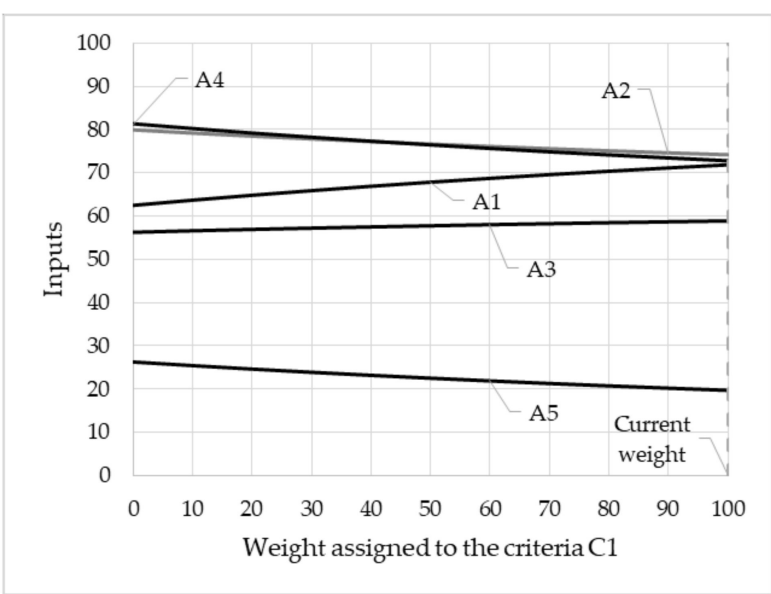

(d)

Figure 3. Sensitivity analysis of attributes: (a) Profitability of the investment project (criteria C8) (b) Generation capacity (criteria C6) (c) Cost of purchasing $\mathrm{CO}_{2}$ emission allowances (criteria C3) (d) Amount of capital expenditure (criteria C1).

\section{Discussion}

The dominant variants A1 and A2 indicated in the course of the analysis meet the electricity production requirement. In the context of the studies carried out, the results obtained may appear to be somewhat skewed. Variant A1 is the most conservative one, and it does not meet the BAT conclusion requirement, which sets the emission limit at 505 $\mathrm{g} / \mathrm{kWh}$. Exceeding the limit specified in the BAT conclusions imposes a limitation on the financial support for the investment but does not preclude its implementation. Variant A2 is an extension of $\mathrm{A} 1$ with $\mathrm{CO}_{2}$ capture, and thus it allows us to meet the environmental requirements. However, such a result was obtained due to the criteria selection method, as well as to the method for assigning the points values in the $V$ matrix. In the case of variant A1, five criteria received 100 points. Variant A2 is mainly inferior due to the increase in energy consumed for the auxiliary power consumption of the generating unit. It can be said that such a result reflects the preferences of a traditional decision-maker perceiving the problem under consideration primarily from the perspective of ensuring the security of supply of the power system and the efficiency of the project itself (so-called: safely and cheaply). The sensitivity analysis indicates that variant A4 should be the most favorable option when changing the weights of the attributes. Its impact increases with the significance of the price of $\mathrm{CO}_{2}$ emission allowances.

Narrowing the choice to the efficiency limit allows the decision-makers to focus their attention on the solutions with the highest potential. The selection of solutions lying on the efficiency frontier requires knowledge and an analysis of the economic capacity of the decision-maker. The complexity and the importance of the problem require the final decision to be supported by a risk analysis of the project. The weighted average ratings of the alternatives determined by the SMART method directly depend on the preferences, knowledge, and intuition of the decision-maker. This imposes the need to assess the stability of solutions in the conditions of changing partial parameters of the assessment-in this case, the weights assigned to the criteria.

The reliability of the obtained results is strongly influenced by the input data. To achieve consistent results and minimize uncertainties caused by different data sources, the technological and economic characteristics of the decision options were based on the same reference study. In practice, the selection of variants and the setting of parameters describing the individual variants should be carried out based on specific data available at the time of the analysis and coming from companies that commercially provide the technologies under analysis. The applied criteria weights are also subject to high uncertainty, in the sense of the variability of these parameters. The weights of the criteria depend on the preferences of the decision-makers, and for the study they were proposed by the authors. In this specific case, the in-depth research on the impact of uncertainty on the criteria weights 
and input data is indicated, to identify which parameters and input data have the greatest impact on the results. An extensive sensitivity analysis of the results should be performed as well. Only results prepared in this way should be presented to decision-makers. It is also expectable that the final decision will be reached through further interactions with the decision-makers and extensions of some of the calculations performed.

The research shows that a SMART method is an effective tool for supporting the selection of electricity generation technologies. The SMART method takes into account the multi-criteria nature of the decision-making problem, allowing for the assessment of decision-making alternatives with qualitative and quantitative criteria in the field of economic, social, and environmental factors, as well as technological innovation, and sustainable development. A characteristic feature of the SMART method is a subjective system for valuing decision options, allowing the preferences of decision-makers to be expressed quantitatively. The method is based on a simple additive model, which makes it accessible and intuitive for potential users. The multi-criteria view of the problem leads to a better understanding of the problem and allows one to focus on each component of the problem separately.

The conducted research leads to the conclusion that the SMART method constitutes a complete tool supporting decision-making concerning the selection of generation sources. The set of comparison criteria proposed by the authors works well for assessing variants of similar technological classes (all considered variants of coal-fired power plants, diversified in terms of their technological and operational parameters). The result of the research is a set of post-comparison criteria, which can be used directly in decision-making concerning the selection of coal-fired generation sources. The application of the SMART method to the assessment of renewable sources, nuclear energy, and their comparison with each other and with coal-fired sources requires further analyses of the set of criteria. The desired set of criteria should enable a differentiation between the alternatives and at the same time allow for a valuable assessment. However, the simplicity of the method may prove to be a limitation when analyzing variants belonging to different technological classes. Such a case should be subject to further studies.

The presented approach can be applied directly by engineers working on similar topics. This may be the case for clean coal technologies, as well as for other technologies used in the electro-energy sector. The presented research approach can be used in energy companies, consulting companies, and state administration as a tool to support decision-makers in planning the development of a diversified generation structure in the long term. The practical application of the approach presented in the paper will allow for the integration of clean coal technologies into the energy mix. It can also be used for performing analysis within the framework of defining national energy policy. Finally, it can be used to compare and select the other groups of energy technologies, such as gas sources, or to compare divergent technologies.

From a practical point of view, this research presents a systematic approach to collecting and presenting the data on the problem. The application of the present approach affects the transparency and the course of the decision-making process, and, above all, it gives managers the freedom to specify their preferences and analyze the results that correspond to those preferences. Each solution can be examined in detail within the framework of sensitivity analysis by performing experiments for variable values of problem parameters. The implementation of the mathematical apparatus of the SMART method, whose complexity is low, indicates the value of comparability of criteria of different natures. The approach has an entirely applicative character.

\section{Conclusions}

The research problem addressed in the paper concerned the selection of sources of clean coal technology applicable in conditions of transformation of the Polish power sector. To solve the research problem, the authors used the SMART multi-criteria decision support method. The research involved a comparative analysis of five technological variants of coal- 
fired power plants considered in terms of nine decision criteria grouped into two categories: project inputs and project outputs. The results of the research indicate that the supercritical power plant and its variant equipped with CCS installation are the most effective solutions in terms of the decision criteria applied. The sensitivity analysis was carried out for the solutions identified during the investigation. The results obtained allow us to conclude that the method proposed in the study provides a relatively stable solution to the problem. In light of the obtained results, the problem posed in the paper can be considered as investigated and solved adequately, given the objectives set and the indicated scope of the work. The conceptual framework is comprehensively explained. The most important conclusion indicates that the SMART method can support technology management at the stage of its selection. A robust analysis of environmental, financial, social, and legal factors at this stage should result in a better preparation at subsequent phases of the technology management process, that is to say, technology acquisition, implementation, and maintenance. The practical application of the approach presented in the paper will support the decision-makers of energy companies in planning the development of the generation structure in a long-term perspective.

The original value of the approach is the application of mathematical modeling and multi-criteria analysis methods to the problem of the selection of clean coal technologies in the Polish power sector. This sector is currently undergoing significant changes, having entered a stage of energy transition. The proposed approach has both a research and a practical dimension. It can be used in power enterprises as a tool to support the planning of the development of a diversified generation structure.

The multidimensional nature of the analyzed problem indicates the need for further research in this area. In-depth research on the impact of uncertainty in criteria weights and input data, supported by extensive sensitivity analyses, appears necessary. Subsequent analyses should confront the results obtained in this paper with the outcomes acquired by applying other methods from the MCDM family. Technology selection is but one of the stages of the technology management process, which makes it necessary to investigate the remaining phases applied in the power sector. The desired result of such research should be the identification and adaptation of tools and methods to support the subsequent stages of the technology management process in the sector. The analysis of the process stages should lead to the creation of a model, integrating the subsequent stages of the technology management process dedicated to the power sector.

Author Contributions: Conceptualization, W.L. and C.S.; methodology, W.L. and C.S.; formal analysis, W.L. and C.S.; investigation, W.L. and C.S.; resources, W.L. and C.S.; writing-original draft preparation, W.L. and C.S.; writing-review and editing, W.L. and C.S.; visualization, W.L. and C.S.; supervision, C.S. All authors have read and agreed to the published version of the manuscript.

Funding: This research received no external funding.

Institutional Review Board Statement: Not applicable.

Informed Consent Statement: Not applicable.

Data Availability Statement: Publicly available datasets were analyzed in this study, according to the References.

Conflicts of Interest: The authors declare no conflict of interest. The funders had no role in the design of the study; in the collection, analyses, or interpretation of data; in the writing of the manuscript, or in the decision to publish the results.

\section{References}

1. National Research Council. Management of Technology: The Hidden Competitive Advantage; National Academy Press: Washington, DC, USA, 1987.

2. Lee, H. Uncovering the Multidisciplinary Nature of Technology Management: Journal Citation Network Analysis. Scientometrics 2015, 102, 51-75. [CrossRef]

3. Gregory, M. Technology Management: A Process Approach. Proc. Inst. Mech. Eng. Part B J. Eng. Manuf. 1995, 209, 347-356. [CrossRef] 
4. Phaal, R.; Farrukh, C.I.D. Probert, Technology Management Process Assessment: A Case Study. Int. J. Oper. Prod. Manag. 2001, 21, 1116-1132. [CrossRef]

5. Cetindamar, D.; Can, O.; Pala, O. Technology Management Activities and Tools: The Practice in Turkey. In Proceedings of the Technology Management for the Global Future-PICMET 2006 Conference, Istanbul, Turkey, 8-13 July 2006; pp. 92-98.

6. Shenoy, S.; Shetty, D.; Rodrigues, L.; Maddodi, B.; Motlagh, F. Industry-Institute Technology Management Practices: A Case Study. In Proceedings of the International Conference on Automation, Computational and Technology Management (ICACTM), London, UK, 24-26 April 2019; pp. 284-287.

7. Liu, Y.; Wu, W.W.Y. The Impacts of Technology Management on Product Innovation: The Role of Technological Capability. IEEE Access 2020, 8, 210722-210732. [CrossRef]

8. Gaynor, G.H. Management of Technology: Description, Scope and Implications. In Handbook of Technology Management; McGrawHill: New York, NY, USA, 1996; pp. 1.3-1.29.

9. Tuncay, C.C.; Cilingir, A. Technology Management Capability Assesment an Empirical Study in Izmir Turkey for Model Development. Eur. Int. J. Sci. Technol. 2013, 2, 176-187.

10. Suharto, Y.; Tugrul, D. Methods and Tools Applied in Strategic Technology Planning. In Research and Technology Management in the Electricity Industry: Methods, Tools and Case Studies; Springer: London, UK, 2013; pp. 1-15.

11. Schaeffer, G.J. Energy Sector in Transformation, Trends and Prospects. Procedia Comput. Sci. 2015, 52, 866-875. [CrossRef]

12. IEA. IEA-Global Energy Review: $\mathrm{CO}_{2}$ Emissions In 2020. IEA. Available online: https://www.iea.org/articles/global-energyreview-co2-emissions-in-2020. (accessed on 23 April 2021).

13. Cetindamar, D.; Phaal, R.; Probert, D. Understanding Technology Management as a Dynamic Capability: A Framework for Technology Management Activities. Technovation 2009, 29, 237-246. [CrossRef]

14. Kumar, A.; Singh, A.R.; Sah, B.; Deng, Y.; He, X.; Kumar, P. A Review of Multi Criteria Decision Making (MCDM) towards Sustainable Renewable Energy Development. Renew. Sustain. Energy Rev. 2017, 69, 596-609. [CrossRef]

15. Sellak, H.; Ouhbi, B.; Frikh, B.F.; Pa, I. Towards Next-Generation Energy Planning Decision-Making: An Expert-Based Framework for Intelligent Decision Support. Renew. Sustain. Energy Rev. 2017, 80, 1544-1577. [CrossRef]

16. Ministry of Climate and Environment. Energy Policy of Poland until 2040; Ministry of Climate and Environment: Warsaw, Poland, 2020.

17. Sobczyk, E.J.; Wota, A.; Kopacz, M.; Fraczek, J. Clean Coal Technologies-A Chance for Poland's Energy Security. DecisionMaking Using AHP With Benefits, Opportunities, Costs and Risk Analysis. Gospod. Surowcami Miner. 2017, 33, 27-48. [CrossRef]

18. Kuchler, M.; Bridge, G. Down the Black Hole: Sustaining National Socio-Technical Imaginaries of Coal in Poland. Energy Res. Soc. Sci. 2018, 41, 136-147. [CrossRef]

19. Melikoglu, M. Clean Coal Technologies: A Global to Local Review for Turkey. Energy Strategy Rev. 2018, 22, 313-319. [CrossRef]

20. Zavadkas, E.K.; Turskis, Z. Multiple Criteria Decision Making (MCDM) Methods in Economics: An Overview/Daugiatiksliai Sprendimu Prièmimo Metodai Ekonomikoje: Apžvalga. Technol. Econ. Dev. Econ. 2011, 17, 397-427. [CrossRef]

21. Kabir, G.; Sadiq, R.; Tesfamariam, S. A Review of Multi-Criteria Decision-Making Methods for Infrastructure Management. Struct. Infrastruct. Eng. 2014, 10, 1176-1210. [CrossRef]

22. Huang, I.B.; Keisler, J.; Linkov, I. Multi-Criteria Decision Analysis in Environmental Sciences: Ten Years of Applications and Trends. Sci. Total. Environ. 2011, 409, 3578-3594. [CrossRef]

23. Taylor, J.M.; Love, B.N. Simple Multi-Attribute Rating Technique for Renewable Energy Deployment Decisions (SMART REDD). J. Def. Modeling Simul. Appl. Methodol. Technol. 2014, 11, 227-232. [CrossRef]

24. Guarnieri, P.R. Decision Models in Engineering and Management; Springer International Publishing: Cham, Germany, $2015 ;$ pp. 1-7.

25. Li, Y.S.; Zhang, S.F. An Analysis of the Multi-Criteria Decision-Making Problem for Distributed Energy Systems. Energies 2018, 11, 2453. [CrossRef]

26. Ishfaq, S.; Ali, S.; Ali, Y. Selection of Optimum Renewable Energy Source for Energy Sector in Pakistan by Using MCDM Approach. Process. Integr. Optim. Sustain. 2018, 2, 61-71. [CrossRef]

27. Shao, M.; Han, Z.; Sun, J.; Xiao, C.; Zhang, S.; Zhao, Y. A Review of Multi-Criteria Decision Making Applications for Renewable Energy Site Selection. Renew. Energy 2009, 157, 377-403. [CrossRef]

28. Ilbahar, E.; Cebi, S.; Kahraman, C. A State-of-the-Art Review on Multi-Attribute Renewable Energy Decision Making. Energy Strategy Rev. 2019, 25, 18-33. [CrossRef]

29. Yazdani, M.; Chatterjee, P.; Zavadskas, E.K.; Streimikiene, D. A Novel Integrated Decision-Making Approach for the Evaluation and Selection of Renewable Energy Technologies. Clean Technol. Environ. Policy 2018, 20, 403-420. [CrossRef]

30. Strantzali, E.; Aravossis, K. Decision Making in Renewable Energy Investments: A Review. Renew. Sustain. Energy Rev. 2016, 55, 885-898. [CrossRef]

31. Li, T.; Li, A.; Guo, X. The Sustainable Development-Oriented Development and Utilization of Renewable Energy Industry-A Comprehensive Analysis of MCDM Methods. Energy 2020, 212, 118694. [CrossRef]

32. Ezbakhe, F.; Pérez-Foguet, A. Decision Analysis for Sustainable Development: The Case of Renewable Energy Planning Under Uncertainty. Eur. J. Oper. Res. 2021, 291, 601-613. [CrossRef]

33. Sitorus, F.; Brito-Parada, P.R. A multiple Criteria Decision Making Method to Weight the Sustainability Criteria of Renewable Energy Technologies under Uncertainty. Renew. Sustain. Energy Rev. 2020, 127, 109891. [CrossRef]

34. Siksnelyte, I.; Zavadskas, E.K. Streimikiene, D.; Sharma, D. An Overview of Multi-Criteria Decision-Making Methods in Dealing with Sustainable Energy Development Issues. Energies 2018, 11, 2754. [CrossRef] 
35. Si, T.; Wang, C.; Liu, R.; Guo, Y.; Yue, S.; Ren, Y. Multi-Criteria Comprehensive Energy Efficiency Assessment Based on Fuzzy-AHP Method: A Case Study of Post-Treatment Technologies for Coal-Fired Units. Energy 2020, 200, 117533. [CrossRef]

36. Wu, D.; Yang, Z.; Wang, N.; Li, C.; Yang, Y. An Integrated Multi-Criteria Decision Making Model and AHP Weighting Uncertainty Analysis for Sustainability Assessment of Coal-Fired Power Units. Sustainability 2018, 10, 1700. [CrossRef]

37. Wang, X. Study on Carbon Capture and Storage (CCS) Investment Decision-Making Based on Real Options for China's Coal-Fired Power Plants. J. Clean. Prod. 2016, 112, 4123-4131. [CrossRef]

38. Nagarkatti, A.; Kolar, A.K. Advanced Coal Technologies for Sustainable Power Sector in India. Electr. J. 2021, 34, 106970. [CrossRef]

39. Ligus, M. Evaluation of Economic, Social and Environmental Effects of Low-Emission Energy Technologies in Poland-MultiCriteria Analysis. Energy Procedia 2017, 136, 163-168. [CrossRef]

40. Saługa, P.W.; Szczepańska-Woszczyna, K.; Miśkiewicz, R.; Chłąd, M. Cost of Equity of Coal-Fired Power Generation Projects in Poland: Its Importance for the Management of Decision-Making Process. Energies 2020, 13, 4833. [CrossRef]

41. Bel, G.; Joseph, S. Policy Stringency Under the European Union Emission Trading System and its Impact on Technological Change in the Energy Sector. Energy Policy 2018, 117, 434-444. [CrossRef]

42. PSE. PSE Dane systemowe.Funkcjonowanie KSE. Raport Roczny 2020. 2021. Available online: https://www.pse.pl/danesystemowe/funkcjonowanie-kse/raporty-roczne-z-funkcjonowania-kse-za-rok/raporty-za-rok-2020 (accessed on 23 April 2021).

43. Zimon, G. An Assessment of the Strategy of Working Capital Management in Polish Energy Companies. Int. J. Energy Econ. Policy 2019, 9, 552-556. [CrossRef]

44. United Nations. Paris Agreement; United Nations: Paris, France, 2015.

45. European Council. Conclusions-23/24 October 2014. 2030 Climate and Energy Policy Framework; European Council: Brussels, Belgium, 2014.

46. European Commission. Communication from the Commission-The European Green Deal; European Commission: Brussels, Belgium, 2019.

47. Michalak, A.; Dziugiewicz, S. Development Limitations and Perspectives of Renewable Energy Sources in Poland. Manag. Syst. Prod. Eng. 2018, 26, 237-240. [CrossRef]

48. Gawlik, L. The Polish Power Industry in Energy Transformation Process. Miner. Econ. 2018, 31, 229-237. [CrossRef]

49. Ministry of Climate and Environment. National Energy and Climate Plan-Assumptions and Objectives and Policies and Actions. In Ministerstwo Klimatu i Środowiska; Ministry of Climate and Environment: Warsaw, Poland, 2019.

50. Gissey, G.C.; Dodds, P.E.; Radcliffe, J. Market and Regulatory Barriers to Electrical Energy Storage Innovation. Renew. Sustain. Energy Rev. 2018, 82, 781-790. [CrossRef]

51. Brauers, H.; Oei, P.-Y. The Political Economy of Coal in Poland: Drivers and Barriers for a Shift Away from Fossil Fuels. Energy Policy 2020, 144, 111621.

52. Broda, W.; Kuboń, M.; Malaga-Tobola, U.; Kwaśniewski, D.; Cupiał, M. Economic and Legal Aspects of Renewable Energy Production in Poland. In Proceedings of the International Multidisciplinary Scientific GeoConference, SGEM, Sofia, Bulgaria, 28 June 2019; pp. 451-458.

53. Piwowar, A.; Dzikuć, M. Development of Renewable Energy Sources in the Context of Threats Resulting from Low-Altitude Emissions in Rural Areas in Poland: A Review. Energies 2019, 12, 3558.

54. European Commission. COMMISSION IMPLEMENTING DECISION (EU) 2017/1442 of 31 July 2017 Establishing Best Available Techniques (BAT) Conclusions, under Directive 2010/75/EU of the European Parliament and of the Council, for Large Combustion Plants", European Commission, Notified under Document C(2017)5225. 2017. Available online: https:/ / eur-lex.europa.eu/legalcontent/EN/TXT/PDF/?uri=CELEX:32017D1442 (accessed on 23 April 2021).

55. Basu, P. Biomass Gasification, Pyrolysis and Torrefaction; Biomass Gasification, Pyrolysis and Torrefactio. In Practical Design and Theory, 3rd ed.; Elsevier: Amsterdam, The Netherlands, 2018; pp. 1-27.

56. Lin, S.; Chen, B.; Chen, W.; Li, W.; Wu, S. Study on Clean Coal Technology with Oil Agglomeration in Fujian Province. Procedia Eng. 2012, 45, 986-992. [CrossRef]

57. Guan, G. Clean coal technologies in Japan: A review. Chin. J. Chem. Eng. 2017, 25, 689-697. [CrossRef]

58. IEA. Energy Technology Perspectives 2017. In Catalysing Energy Technology Transformations; IEA-International Energy Agency: Parise, France, 2017.

59. Costa-Campi, M.T.; Jamasb, T.; Trujillo-Baute, E. Economic Analysis of Recent Energy Challenges: Technologies, Markets, and Policies. Energy Policy 2018, 118, 584-587. [CrossRef]

60. Bischoff, M.; Jahn, J. Economic Objectives, Uncertainties and Decision Making in the Energy Sector. J. Bus. Econ. 2016, 86, 85-102. [CrossRef]

61. Lee, J.; Yang, J.-S. Government R\&D investment decision-making in the energy sector: LCOE foresight model reveals what regression analysis cannot. Energy Strategy Rev. 2018, 21, 1-15. [CrossRef]

62. Michalski, M. Wspomaganie Decyzji o Budowie Elektrowni Jądrowych Metodami Electre. Przeglad Organ. 2019, 12-18. [CrossRef]

63. French, S.; Roy, B. Multicriteria Methodology for Decision Aiding. J. Oper. Res. Soc. 1996, 48, 1257. [CrossRef]

64. Keeney, R.L.; Raiffa, H. Decisions with Multiple Objectives: Preferences and Value; Wiley: New York, NY, USA, 1976.

65. Lootsma, F.A. Multi-Criteria Decision Analysis via Ratio and Difference Judgement; tom v. 29; Kluwer Academic Publishers: Dordrecht, The Netherlands; Boston, MA, USA, 1999.

66. Vincke, P. Recent Progresses in Multicriteria Decision-Aid. Riv. Di Mat. Per Le Sci. Econ. E Soc. 1994, 17, 21-32. [CrossRef]

67. Zardari, N.H.; Ahmed, K.; Shirazi, S.M.; Bin Yusop, Z. Weighting Methods and their Effects on Multi-Criteria Decision Making Model Outcomes in Water Resources Management; Briefs in Water Science and Technology; Springer: Basingstoke, UK, 2015. [CrossRef] 
68. Triantaphyllou, E. Multi-Criteria Decision Making Methods: A Comparative Study; Springer US: Boston, MA, USA, 2000.

69. Gavade, R.K. Multi-Criteria Decision Making: An Overview of Different Selection Problems and Methods. Int. J. Comput. Sci. Inf. Technol. 2014, 5, 5643-5646.

70. Zavadskas, E.K.; Turskis, Z.; Kildienè, S. State of Art Surveys of Overviews on MCDM/MADM Methods. Technol. Econ. Dev. Econ. 2014, 20, 165-179. [CrossRef]

71. Durbach, I.N.; Stewart, T.J. Modeling Uncertainty in Multi-Criteria Decision Analysis. Eur. J. Oper. Res. 2012, 223, 1-14. [CrossRef]

72. Edwards, W. Social Utilities. In Proceedings of the Engineering Economist Summer Symposium Series; ACS Publications: Washington, DC, USA, 1971; Volume 6, pp. 119-129.

73. Siregar, D.; Arisandi, D.; Usman, A.; Irwan, D.; Rahim, R. Research of Simple Multi-Attribute Rating Technique for Decision Support. J. Phys. Conf. Ser. 2017, 930, 012015. [CrossRef]

74. Rahim, R. Study of the Simple Multi-Attribute Rating Technique for Decision Support. IJSRST 2016, 2, 491-494.

75. Goodwin, P.; Wright, G. Decision Analysis for Management Judgment, 5th ed.; Wiley: Hoboken, NJ, USA, 2014.

76. Yilmaz, B.; Harmancioglu, N. Multi-Criteria Decision Making for Water Resource Management: A Case Study of the Gediz River Basin, Turkey. Water SA 2010, 36, 563-576. [CrossRef]

77. IEAGHG. Capture at Coal Based Power and Hydrogen Plants; IEA Environmental Projects Ltd. (IEAGHG): Cheltenham, UK, 2015.

78. Wiśniewski, G.; Curkowski, A.; Pejas, B. Scenariusz Średnich Kosztów Energii Elektrycznej Do Roku 2050 Oraz Cen W Taryfach Za Energię Elektryczną Dla Wybranych Grup Odbiorców Do Roku 2030. Energetyka Społeczeństwo Polityka 2017, 6, 53-80.

79. CIRE. $\mathrm{CO}_{2}$ Emissions Trading CIRE. Available online: https://handel-emisjami-co2.cire.pl/st,34,514, me,0,0,0,0,0,cenyuprawnien-do-emisji-co2.html (accessed on 25 April 2021).

80. Energy Regulatory Office. Average Electricity Price in the OTC Market in the First Quarter of 2021. 2021. Available online: https:/ / www.ure.gov.pl/pl/urzad/informacje-ogolne/aktualnosci/9402,Srednia-cena-energii-elektrycznej-na-rynkupozagieldowym-w-pierwszym-kwartale-20.html (accessed on 25 April 2021).

81. IEA. International Energy Agency. 2019. Available online: https://www.iea.org/subscribe-to-data-services/co2-emissionsstatistics (accessed on 29 November 2020). 